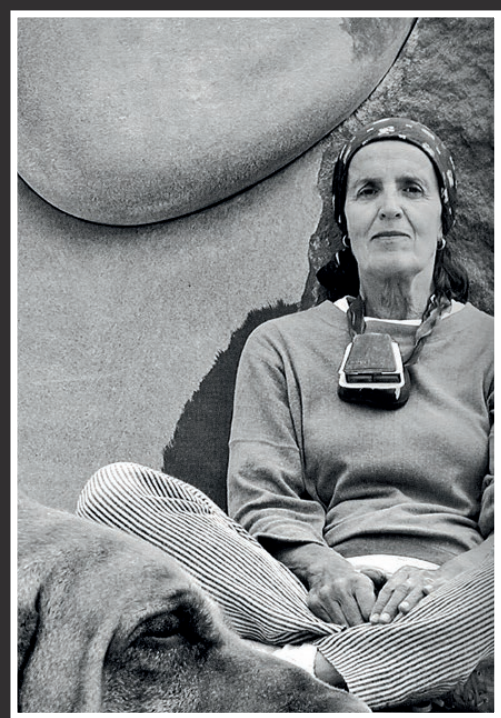

Lika Mutal: Fotografía de Patricia Arena, Catálogo: "Entre magma y madre: la piedra ancestral". Galería Lucía de la Puente, 2003.

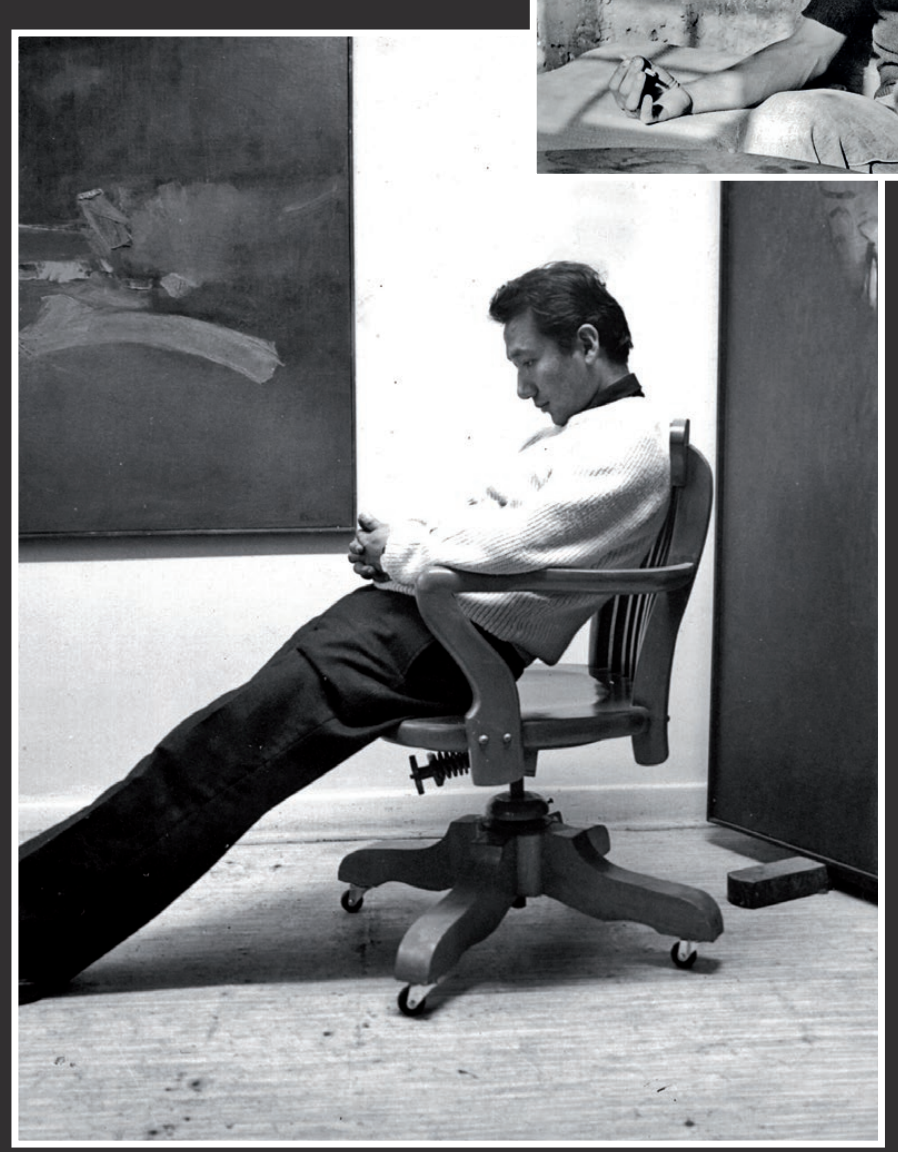

Venancio Shinki / Fotografía: Baldomero Pestana / Archivo ICPNA
ILLAPA dedica los versos que siguen a los amigos que se han ido. Provienen de una gran obra musical de Gustav Mahler titulada Das Lied von der Erde (El canto de la tierra) que expresa, como nunca antes se había hecho, un canto a la vida, embriagante y a la vez melancólico, también una despedida.

Luis Arias Vera, Lika Mutal, Juan Javier Salazar y Venancio Shinki vivirán entre nosotros a través de las obras que nos han dejado.

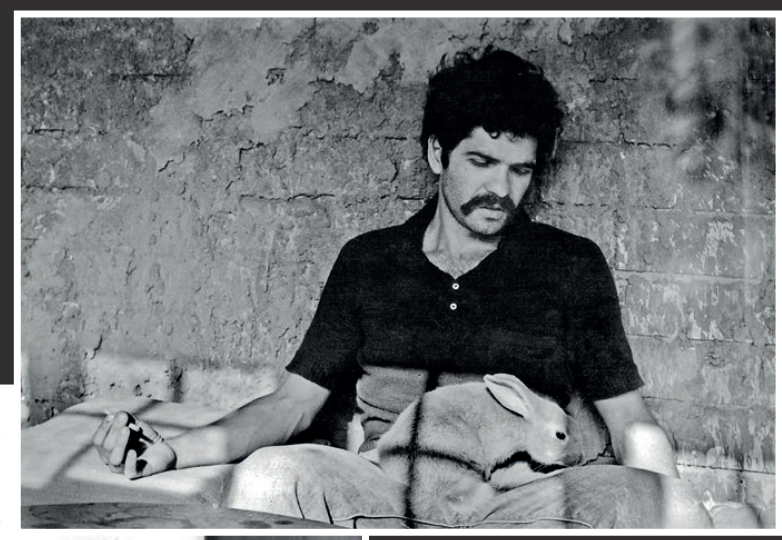

Juan Javier Salazar / Fotografía: Hermán Schwarz 


\section{LA DESPEDIDA}

El sol desaparece detrás de las montañas.

La tarde cae sobre todos los valles

Con sus sombras plenas de frescura.

iOh, mira! Como una barca de plata

La luna boga hacia el lago azul del cielo.

iSiento el soplo del viento ligero

Detrás de los pinos en sombra!

El arroyo melodioso canta en la oscuridad

Y las flores palidecen en la penumbra.

La tierra respira ahíta de silencio y de sueño.

Todos los deseos se convierten en deseos.

Los hombres cansados vuelven a sus hogares

Para encontrar de nuevo en el sueño,

La felicidad olvidada y la juventud.

Las aves se posan silenciosas en las ramas.

iEl mundo descansa!

El viento es fresco a la sombra de los pinos.

Estoy aquí esperando impaciente a mi amigo

Para el último adiós.

Ansío, iOh amigo! Gustar en tu compañía

La belleza de esta tarde.

¿Dónde estás? Me has abandonado largo tiempo.

Voy errante con mi laúd en la mano

Por caminos llenos de mullida yerba.

iOh belleza! iOh mundo eternamente ebrio de amor y de vida!

El desciende del caballo y le acerca la bebida del adiós.

El le pregunta donde conducirá sus pasos

y por qué tiene que ser así.

Habló con voz velada:

Oh amigo mío

La felicidad no me ha sonreído en este mundo.

¿A dónde voy? Voy errante por las montañas,

Busco reposo para mi corazón solitario.

Voy a mi país, hacia mi hogar,

Nunca me aventuraría más lejos.

Mi corazón está tranquilo esperando su hora.

La tierra bien amada por todas partes florece en primavera

$Y$ reverdece de nuevo, para todos y siempre.

Los horizontes brillan azules.

Eternamente...Eternamente...

(Mong-Kao-Yen y Wang-Wei) 